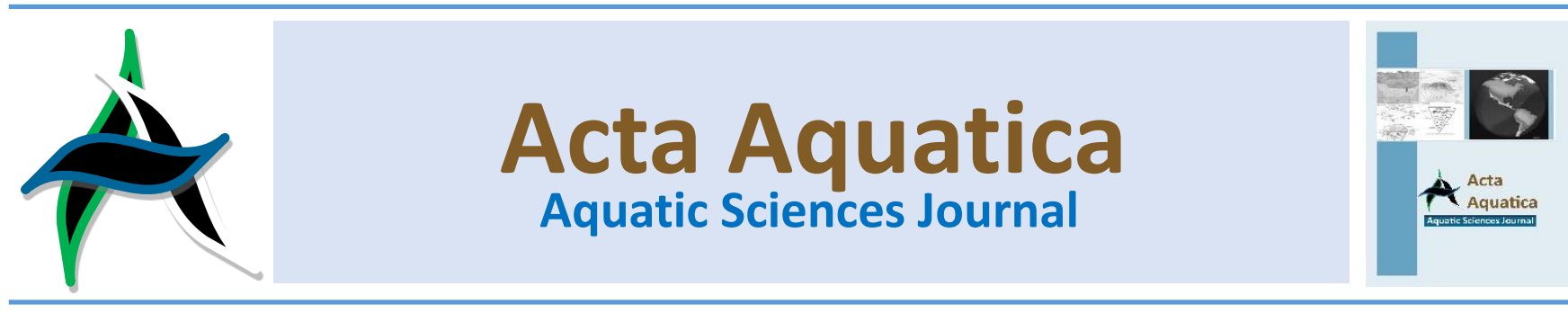

\title{
Pengaruh salinitas terhadap kondisi fisiologi pada benih ikan bawal bintang (Trachinotus blochii)
}

\section{The effect of salinity on the physiological condition of silver pompano (Trachinotus blochii)}

\author{
Riri Ezraneti ${ }^{a, *}$, Saiful Adhar ${ }^{b}$ dan Aula Maretta Alura ${ }^{b}$ \\ a Program Studi IImu Kelautan, Fakultas Pertanian, Universitas Malikussaleh, Aceh, Indonesia \\ a Program Studi Akuakultur, Fakultas Pertanian, Universitas Malikussaleh, Aceh, Indonesia
}

\begin{abstract}
Abstrak
Penelitian ini bertujuan untuk menentukan Laju konsumsi oksigen, pertumbuhan dan kelangsungan hidup ikan bawal bintang yang dipelihara dalam salinitas yang berbeda. Penelitian ini dilakukan dengan memelihara ikan dalam jaring kontainer dengan salinitas yang berbeda menggunakan 4 perlakuan dan 3 ulangan: A: 32 ppt, B: 24 ppt C: 19 ppt D: 14 ppt selama 28 hari. Parameter penelitian yang diamati adalah laju konsumsi oksigen, pertumbuhan panjang dan bobot, efisiensi pakan dan tingkat kelangsungan hidup dan parameter kualitas air yang meliputi salinitas $(\%)$, suhu $\left({ }^{\circ} \mathrm{C}\right), \mathrm{DO}(\mathrm{mg} / \mathrm{L}), \mathrm{pH}$ dan amonia. Hasil penelitian menunjukkan bahwa laju konsumsi oksigen berbeda sangat nyata antar perlakuan dengan konsumsi oksigen terbaik dalam perawatan C (19\%) dan D (14\%) sebesar 0,47 mg $\mathrm{O}_{2} / \mathrm{g} / \mathrm{jam}$. Pertumbuhan panjang terbesar pada perlakuan $\mathrm{D}$ (14 $\%$ ) sebesar $1,52 \mathrm{~cm}$, sedangkan pertambahan bobot terbesar terdapat pada C (19\%) sebesar 2,72 gram. Efisiensi pakan tidak berbeda nyata antar perlakuan dengan nilai terbaik sebesar 8,94 \% yang terdapat pada perlakuan C (19\%o), sedangkan tingkat kelangsungan hidup berbeda nyata antar perlakuan dengan perlakuan terbaik terdapat pada perlakuan D (14\%) sebesar $100 \%$. Kualitas air masih dalam kisaran yang aman dengan kisaran suhu 26,3-30,5 ${ }^{\circ} \mathrm{C}$, DO 5,25-6,12 mg/L, pH 7,8-8,2 dan amonia $0,16-0,24 \mathrm{mg} / \mathrm{L}$. Ikan bawal bintang dapat hidup secara optimal pada rentang salinitas $14-19$ ppt.
\end{abstract}

\begin{abstract}
This study aims to determine the rate of oxygen consumption, growth and survival rate of silver pompano fish that reared in different salinity. This research was conducted by keeping silver pompano in container nets with different salinity using 4 treatment and 3 replications: A: 32 ppt, B: 24 ppt C: 19 ppt D: 14 ppt for 28 days. The research parameters observed were the rate of oxygen consumption, growth rate, feed efficiency and survival rate and water quality parameters including salinity (\%o), temperature $\left({ }^{\circ} \mathrm{C}\right), \mathrm{DO}(\mathrm{mg} / \mathrm{L}), \mathrm{pH}$ and ammonia. The results showed that the oxygen consumption rate was significantly different with the best oxygen consumption in treatment $\mathrm{C}$ (19 $\%$ ) and $\mathrm{D}\left(14 \%\right.$ ) treatment by $0.47 \mathrm{mgO}_{2} / \mathrm{g} /$ hour. The highest growth in treatment $D(14 \%)$ with 1,52 in length, while the highest growth in the treatment C (19\%) with 2,72 in weight. The feed efficiency is not significantly different between the treatments with the highest value around $8,94 \%$ in the treatment C (19\%o), while survival rate was different between the treatments with the best treatment in $\mathrm{D}(14 \%)$ by $100 \%$. Water quality is still within safe range i.e. temperature between 26,3-30,5 ${ }^{\circ} \mathrm{C}$, DO between 5,25-6,12 mg/L, pH 7,8-8,2 and ammonia $0,16-0,24 \mathrm{~g} / \mathrm{L}$. The silver pompano would live optimally in the salinity range $14-19 \mathrm{ppt}$.
\end{abstract}

Keywords: Silver pompano; salinity; physiological condition

\footnotetext{
* Corresponding author: Program Studi Ilmu Kelautan, Fakultas Pertanian, Universitas Malikussaleh. Jl. Universitas. Kec. Muara Batu, Kabupaten Aceh Utara, Provinsi Aceh, 20155, Indonesia.

Tel: +62-645-41373 Fax: +62-645-59089

e-mail: ririezraneti@unimal.ac.id

doi: https://doi.org/10.29103/aa.v6i2.1621
}

\section{Pendahuluan}

Ikan bawal bintang (Trachinotus blochii) merupakan salah satu jenis ikan air laut yang mempunyai potensi sangat bagus untuk dibudidayakan. Pada tahun 2007, pembenihan ikan bawal bintang sudah berhasil di Balai Budidaya Laut Batam yang pertama kali di Indonesia (Minjoyo et al., 2008). Ikan bawal bintang sekilas memang terlihat seperti bintang, dengan bentuk tubuhnya yang gepeng, ikan bawal bintang cocok untuk 
dibudidayakan karena dapat dilihat dari pertumbuhan yang cepat yaitu 6 sampai 8 bulan, kualitas daging yang baik dan permintaan pasar tinggi. Ikan bawal bintang memiliki jaminan pasar dalam negeri maupun ekspor yang terbuka lebar di berbagai negara seperti Jepang, Hongkong, Taiwan, China dan Kanada (KKP, 2012).

Perpindahan media dari laut ke air payau merupakan salah satu teknik yang berpotensi dikembangkan untuk meningkatkan produksi ikan. Ikan bawal bintang mempunyai sifat euryhaline yaitu tahan terhadap perubahan salinitas sehingga berpeluang untuk dapat dipelihara pada salinitas rendah. Namun untuk menunjang pertumbuhan yang optimal pada ikan bawal bintang perlu kisaran salinitas yang sesuai. Hingga saat ini kegiatan pemeliharaan benih bawal bintang belum diketahui standar salinitas yang optimal untuk pertumbuhan dan kelangsungan hidupnya. Salinitas diketahui dapat mengganggu kehidupan ikan, baik dari sisi fisiologi, tingkah laku, nafsu makan maupun kelangsungan hidupnya.

Beberapa aspek fisiologi ikan yang dipengaruhi oleh salinitas adalah tekanan osmotik, tekanan cairan tubuh dan kebutuhan oksigen. Tingkat kosumsi oksigen salah satu aspek penting yang berpengaruh pada kehidupan dan juga pertumbuhan ikan. Oksigen merupakan faktor pembatas, apabila ketersediaannya di dalam air tidak tercukupi untuk kebutuhan ikan, maka akan berpengaruh terhadap aktivitas dan pertumbuhan ikan serta dapat menimbulkan kematian. Berdasarkan informasi diatas, perlu dilakukan penelitian lebih lanjut mengenai Pengaruh Salinitas Terhadap Kondisi Fisiologi pada Benih ikan bawal bintang untuk melihat laju konsumsi oksigen, pertumbuhan, efesiensi pakan dan kelangsungan hidup.

\section{Bahan dan metode}

\subsection{Bahan dan alat}

Penelitian ini dilaksanakan selama 2 bulan di Laboratorium Bahan dan alat yang digunakan dalam penelitian adalah benih bawal bintang dengan $5 \mathrm{~cm}$, air laut, air tawar, aquades, bak fiber, jaring, pipa paralon, pipa L, pipa outlet, tali tambang dan batu, selang, botol pelet, selang sipon, instalasi aerasi, toples 1 liter, timbangan digital, thermometer, $\mathrm{pH}$ meter dan DO meter.

\subsection{Metode penelitian}

Penelitian ini menggunakan metode eksperimental dengan menggunakan berbagai tingkat salinitas yang berbeda pada setiap perlakuan dengan Rancangan Acak Lengkap (RAL) non faktorial menggunakan 4 perlakuan dan 3 ulangan sebagai berikut:

$\begin{array}{lll}\text { Perlakuan A } & : & \begin{array}{l}\text { Benih ikan bawal bintang dipelihara } \\ \text { pada salinitas } 32 \mathrm{ppt} \text { (Kontrol) }\end{array} \\ \text { Perlakuan B } & : \begin{array}{l}\text { Benih ikan bawal bintang dipelihara } \\ \text { pada salinitas } 24 \mathrm{ppt}\end{array} \\ \text { Perlakuan C } \quad: \begin{array}{l}\text { Benih ikan bawal bintang dipelihara } \\ \text { pada salinitas } 19 \mathrm{ppt}\end{array} \\ \text { Perlakuan D } \quad: \begin{array}{l}\text { Benih ikan bawal bintang dipelihara } \\ \text { pada salinitas } 14 \mathrm{ppt}\end{array}\end{array}$

Kadar salinitas di atas mengambil acuan Berdasarkan McMaster et al. (2005) yang menyatakan Ikan bawal bintang berkerabat dekat dengan Ikan bawal Florida (T. carolimus) yang dapat dibudidayakan pada salinitas 19-12 ppt dan tahan terhadap perubahan mendadak dari media air bersalinitas $32 \mathrm{ppt}$ ke 19 ppt. Selanjutnya menurut Retnani dan Abdulgani (2013), pertumbuhan ikan bawal bintang yang baik yaitu pada salinitas 24 ppt dan untuk tingkat kelangsungan hidup mampu bertahan pada salinitas 4 ppt dengan SR $100 \%$.

\subsection{Prosedur penelitian}

\subsubsection{Penyiapan wadah dan persediaan air}

Wadah dan instalasi aerasi yang digunakan terlebih dahulu dibersihkan menggunakan sikat dan spon, kemudian dibilas sampai bersih menggunakan air laut. Wadah uji yang digunakan saat penelitian yaitu bak fiber dengan kapasitas air 2.5 ton sebanyak 4 buah selanjutnya wadah diberi sekat berupa jaring dengan ukuran jaring $50 \mathrm{~cm} \times 50 \mathrm{~cm} \times 50 \mathrm{~cm}^{3}$ dengan ketinggian air $35 \mathrm{~cm}$ pada setiap media pemeliharaan sebanyak 3 buah pada masing-masing bak fiber untuk setiap perlakuannya. Air yang digunakan pada penelitian adalah air laut dengan kadar salinitas 32 ppt. Untuk mendapatkan salinitas media pemeliharaan sesuai dengan yang diinginkan, maka dilakukan penambahan air tawar dengan menggunakan rumus pengenceran sebagai berikut:

$$
M_{1} \times V_{1}=M_{2} \times V_{2}
$$

Keterangan :

$\mathrm{V}_{1} \quad=$ Volume air laut (Itr)

$\mathrm{M}_{1} \quad$ = Salinitas air laut mula-mula (ppt)

$\mathrm{V}_{2} \quad$ = Volume setelah pengenceran (Itr)

$\mathrm{M}_{2}$ = Salinitas yang diinginkan (ppt)

\subsubsection{Aklimatisasi dan pemeliharaan ikan}

Benih Ikan bawal bintang sebelum dipelihara pada salinitas perlakuan sebenarnya, maka benih diaklimatisasi terlebih dahulu terhadap salinitas secara bertahap. Penurunan salinitas yang dilakukan pada ketiga wadah masing - masing sebanyak $3 \mathrm{ppt} / \mathrm{hari}$. Kemudian ikan yang telah diaklimatisasi dipelihara selama 2 hari sampai ikan terlihat tidak stress dan ikan tersebut mau mengkonsumsi pakan yang diberikan. Penebaran ikan ke dalam jaring dilakukan pada pagi hari agar ikan tidak stress. Padat penebaran yang dilakukan sebanyak 10 ekor per perlakuan, sehingga total benih yang ada pada 12 jaring sebanyak 120 ekor.

\subsubsection{Pemberian pakan}

Ikan bawal bintang cenderung bersifat omnivora, dimana berbagai jenis pakan akan dimangsa, namun yang paling baik adalah pemberian pakan buatan. Pakan yang diberikan berupa pellet yang ukurannya disesuaikan dengan bukaan mulut ikan, dengan merek dagang Megami no 1 dengan kandungan protein sebesar $46 \%$. Pemberian pakan dilakukan secara at satiation sebanyak dua kali sehari yaitu pada pukul 07.00 WIB dan pada pukul 14.00 WIB.

\subsubsection{Pengelolaan kualitas air}

Pengelolaan kualitas air dilakukan dengan cara melakukan pergantian air melalui penyiponan yang dilakukan sebanyak dua kali sehari setelah pemberian pakan. Selain itu pengecekan kualitas air juga dilakukan dengan mengukur parameter kualitas air pada pagi hari. 


\subsection{Parameter pengamatan}

Parameter yang diamati selama penelitian adalah sebagai berikut:

\section{Pengukuran laju kosumsi oksigen}

Pengamatan laju kosumsi oksigen dilakukan dengan sistem tertutup dalam air diam. Laju konsumsi oksigen dapat dihitung menggunakan rumus:

$$
\frac{d 02}{d t}=\frac{(D O g-D O y) V}{(g x t)}
$$

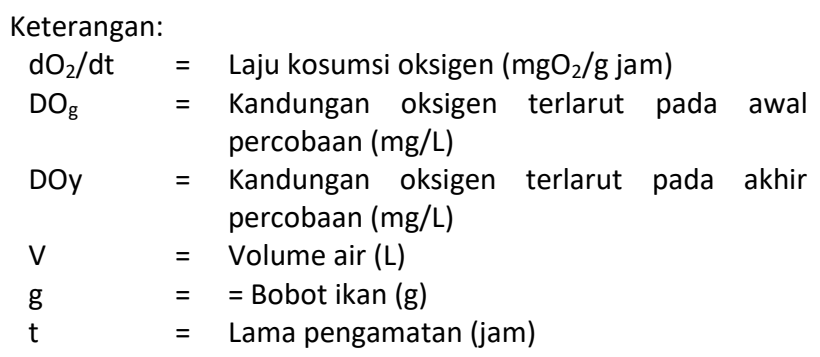

Pertambahan bobot mutlak

Pengukuran bobot tubuh ikan dilakukan dengan cara mengambil seluruh biota uji pada benih bawal bintang sebanyak 10 ekor menggunakan seser. Penimbangan bobot dilakukan setiap 1 minggu sekali, hingga akhir pemeliharaan. Pertambahan bobot dihitung dengan menggunakan rumus Effendie (1979) yaitu :

$$
W m=W_{t}-W_{0}
$$

\section{Keterangan:}

$\mathrm{Wm}$ = Pertumbuhan bobot mutlak (g)

$\mathrm{Wt} \quad=$ Bobot rata-rata individu pada akhir penelitian (g)

Wo = Bobot rata-rata individu pada awal penelitian $(\mathrm{g})$

\section{Pertumbuhan panjang mutlak}

Pengukuran pertambahan panjang tubuh ikan dilakukan dengan cara megukur seluruh biota uji sebanyak 10 ekor. Pengukuran dilakukan 1 minggu sekali. Pertumbuhan panjang mutlak dapat diukur menggunakan rumus (Effendi, 1979):

Keterangan :

$$
P P M=L t-L O
$$

PPM = Pertumbuhan panjang mutlak $(\mathrm{cm})$

Lt $\quad=$ Panjang rata-rata ikan pada waktu $\mathrm{t}(\mathrm{cm})$

LO = panjang rata-rata ikan pada awal percobaan $(\mathrm{cm})$

\section{Efesiensi pakan}

Penghitungan Efisiensi pakan dengan rumus Zonneveld et al. (1991) sebagai berikut:

\section{Keterangan :}

$$
E P=\frac{(W t+D)-W o}{F} \times 100 \%
$$

$\mathrm{EP} \quad=$ Efisiensi pakan (\%)

$\mathrm{Wt} \quad=$ Bobot ikan uji pada akhir penelitian (g)

Wo = Bobot ikan uji pada awal penelitian (g)

$\mathrm{D}=$ Bobot total ikan yang mati selama pemeliharaan (g)

$\mathrm{F} \quad=$ Jumlah total pakan yang diberikan $(\mathrm{g})$

\section{Kelangsungan hidup (survival rate)}

Pengamatan jumlah benih ikan bawal bintang yang hidup, dihitung pada awal dan akhir penelitian dengan cara menghitung seluruh jumlah total benih yang hidup yaitu dengan menggunkan rumus sebagai berikut:

$$
\mathrm{SR}=\mathrm{Nt} / \mathrm{N}_{0} \times 100 \%
$$

Keterangan:

SR = Tingkat kelangsungan hidup \%

$\mathrm{Nt}=$ Jumlah benih yang hidup pada akhir penelitian (ekor)

$\mathrm{N}_{0}=$ Jumlah benih yang hidup pada awal penelitian (ekor)

Kualitas air

Pengukuran kualitas air yang dilakukan meliputi kualitas air fisika dan kimia air yaitu suhu, salinitas, $\mathrm{pH}$, oksigen terlarut dan amonia. Pengukuran kualitas air dilakukan seminggu sekali.

\section{Hasil dan pembahasan}

\subsection{Hasil}

\subsubsection{Laju konsumsi oksigen}

Laju konsumsi oksigen ikan uji dapat dilihat pada Gambar 1 berikut.

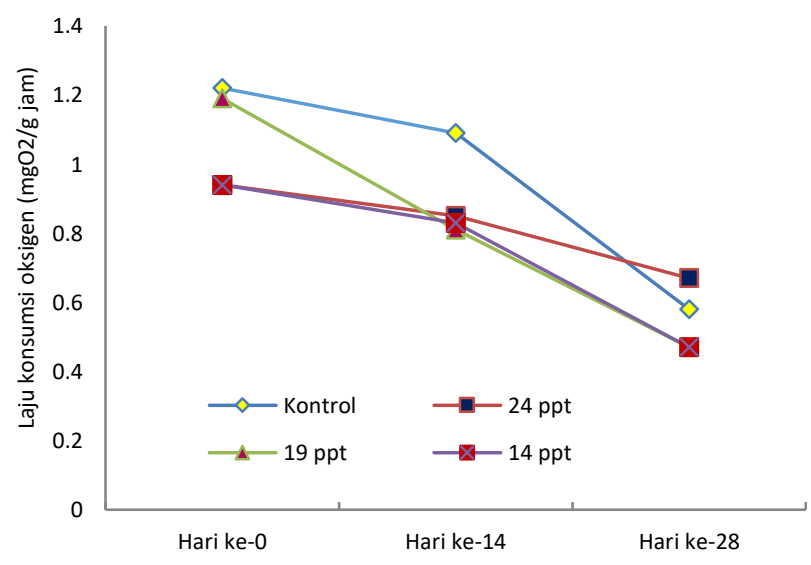

Gambar 1. Grafik laju konsumsi oksigen terhadap salinitas yang berbeda pada benih bawal bintang (T. blochii).

Laju konsumsi oksigen terbesar terdapat pada perlakuan B (24 ppt) dengan nilai sebesar $0,67 \mathrm{mgO}_{2} / \mathrm{g}$ jam, selanjutnya pada perlakuan $A$ (Kontrol) dengan jumlah konsumsi oksigen sebesar $0,58 \mathrm{mgO}_{2} / \mathrm{g}$ jam, kemudian pada perlakuan C (19 ppt) dan $\mathrm{D}$ (14 ppt) sama sebesarnya dengan nilai $0.47 \mathrm{mgO}_{2} / \mathrm{g}$ jam.

\subsubsection{Pertambahan panjang dan pertambahan bobot}

Rata-rata pertambahan panjang benih bawal bintang dapat dilihat pada Grafik 2. Berdasarkan hasil penelitian yang diperoleh, pertambahan panjang yang tertinggi pada perlakuan A (Kontrol) dengan nilai rata-rata $1,78 \mathrm{~cm}$, kemudian pada perlakuan $D(14 \mathrm{ppt})$ dengan nilai rata-rata $1,52 \mathrm{~cm}$, perlakuan $\mathrm{B}$ (24 ppt) dengan nilai rata-rata1,44 cm, dan pertumbuhan panjang yang rendah yaitu pada perlakuan C (19 ppt) dengan nilai rata-rata $1,41 \mathrm{~cm}$. 


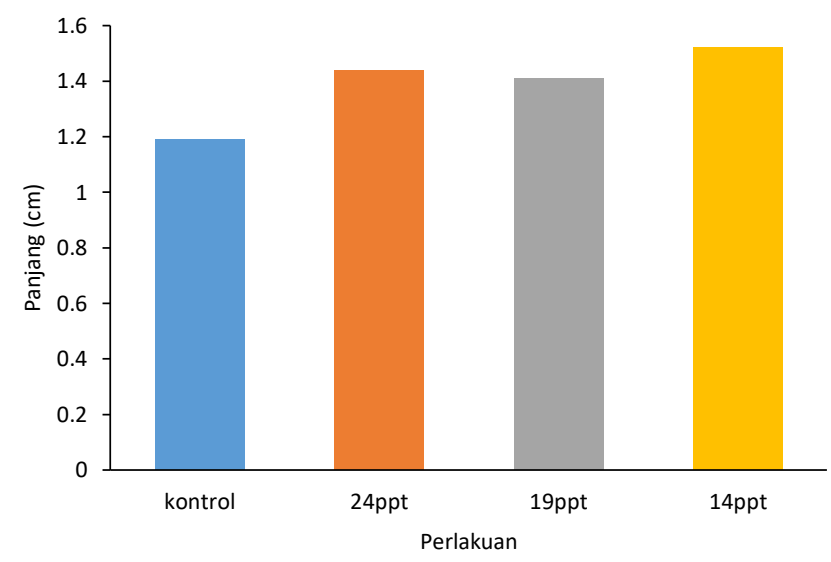

Gambar 2. Grafik pertambahan panjang terhadap salinitas yang berbeda pada benih bawal bintang (T. blochii)

Rata-rata pertambahan bobot pada salinitas yang berbeda pada benih bawal bintang (Gambar 3) adalah sebagai berikut.

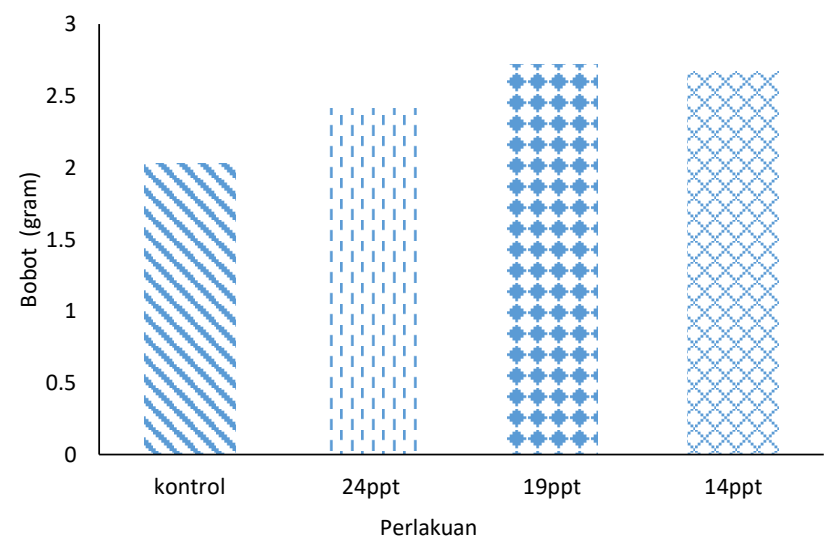

Gambar 3. Grafik pertambahan bobot terhadap salinitas yang berbeda pada benih bawal bintang (T. blochii).

Berdasarkan hasil pengukuran pertambahan bobot terbesar yaitu pada perlakuan $\mathrm{C}$ (19 ppt) denga bobot rata-rata 2,72 gram, D (14 ppt) dengan bobot rata-rata 2,67 gram, B (24 ppt) dengan bobot rata-rata 2,41 gram, sedangkan kontrol dengan bobot rata-rata 2,03 gram.

\subsubsection{Efesiensi pakan}

Rata-rata efesiensi pakan pada benih bawal bintang adalah sebagai berikut.

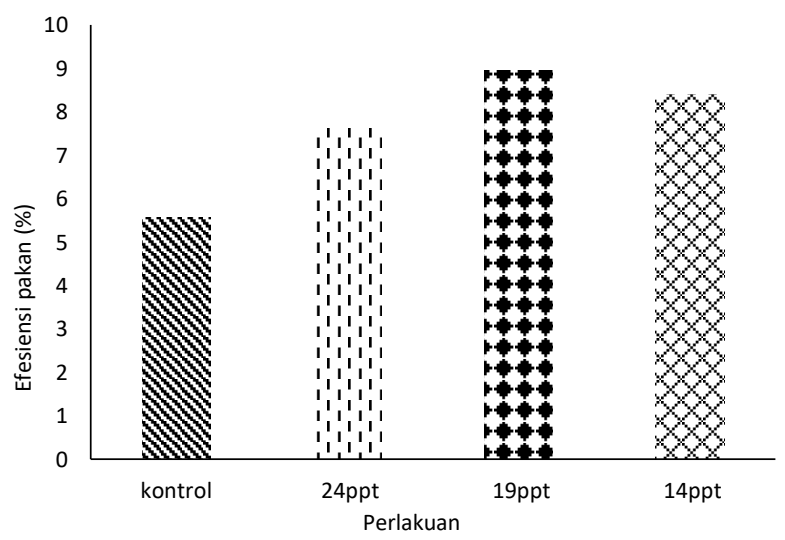

Gambar 4. Grafik efesiensi pakan terhadap salinitas yang berbeda pada benih Bawal bintang (T. blochii).

\subsubsection{Tingkat kelangsungan hidup (survival rate)}

Grafik rata-rata kelangsungan hidup pada benih bawal bintang dapat dilihat sebagai berikut.

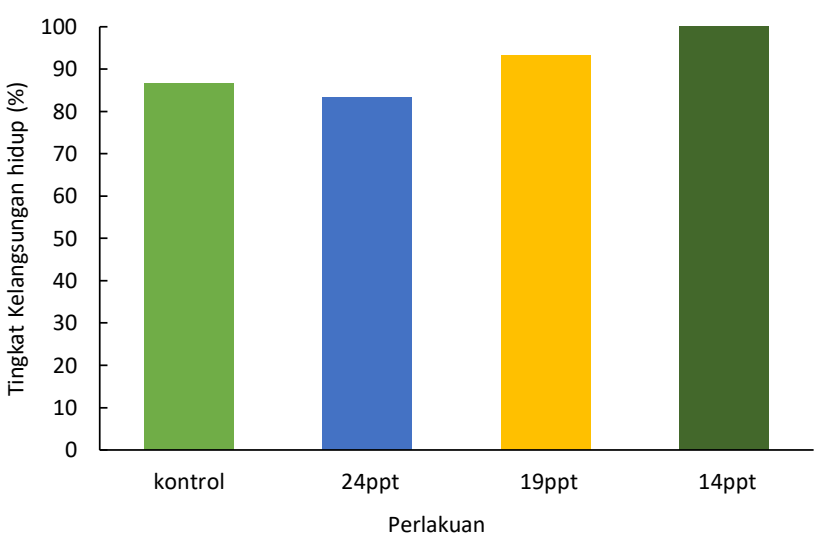

Gambar 5. Tingkat kelangsungan hidup terhadap salinitas yang berbeda pada benih bawal bintang ( $T$. blochii)

\subsubsection{Kualitas air}

Adapun kualitas air yang diperoleh selama penelitian yaitu masih dalam batas aman untuk pemeliharaan benih ikan bawal bintang dapat dilihat pada Tabel 1. sebagai berikut:

Tabel 1

Kisaran nilai kualitas air pada media pemeliharaan benih bawal bintang dengan salinitas berdeda.

\begin{tabular}{lccccc}
\hline Perlakuan & $\begin{array}{c}\text { Salinitas } \\
(\mathrm{ppt})\end{array}$ & $\begin{array}{c}\text { Suhu } \\
\left({ }^{\circ} \mathrm{C}\right)\end{array}$ & $\begin{array}{c}\mathrm{DO} \\
(\mathrm{ppm})\end{array}$ & $\mathrm{pH}$ & $\begin{array}{c}\text { Amonia } \\
(\mathrm{ppm})\end{array}$ \\
\hline A (kontrol) & $28-33$ & $27,5-30,5$ & $5.98-6.11$ & $8.01-8.09$ & 0,20 \\
B (24 ppt) & 24 & $26,8-28,4$ & $5.80-6.08$ & $8.05-8.14$ & 0,24 \\
C (19 ppt) & 19 & $26,5-28,1$ & $5.25-6.12$ & $8.07-8.27$ & 0,19 \\
D (14 ppt) & 14 & $26,3-27,9$ & $5.29-6.02$ & $7.89-8.17$ & 0,17 \\
Air Tawar & - & - & - & - & 0,16 \\
\hline
\end{tabular}

Kualitas air yang diperoleh selama penelitian untuk salinitas yang berbeda, pada wadah kontrol 28-32 ppt, sedangkan wadah B (24 ppt), C (19 ppt) dan D (14 ppt), kisaran suhu untuk setiap perlakuan $26,3-27,9^{\circ} \mathrm{C}, \mathrm{pH} 7,89-8,27$, DO 5,256,12 dan amonia selama pemeliharaan 0,16-0,24.

\subsection{Pembahasan}

Tingkat Laju konsumsi oksigen pada ikan ialah banyaknya oksigen yang dikonsumsi oleh biota akuatik dalam waktu tertentu dan ukuran ikan, kemudian juga berhubungan dengan kadar oksigen yang terdapat pada suatu perairan. Tingkat konsumsi oksigen juga menunjukkan tingkat metabolisme pada suatu organisme. Metabolisme merupakan proses-proses perubahan kimia (transformasi materi dan energi) yang berlangsung secara kontinu di dalam sel makhluk hidup. Dari hasil penelitian ini dapat dilihat bahwa $F_{\text {hitung }} 8.755291>F_{\text {tabel }} 5 \%$ $(4,07)$ dan $1 \%(7,59)$ yang artinya perlakuan salinitas yang berbeda berpengaruh sangat nyata terhadap laju konsumsi oksigen pada benih ikan bawal bintang (Trachinotus blochii).

Keberadaan oksigen dipengaruhi salah satunya oleh suhu yang ada pada perairan tersebut, sehingga mempengaruhi proses pertukaran zat atau metabolisme makhluk hidup di dalamnya (Asnawi, 1993). Selanjutnya Affandi dan Tang (2002) menyatakan bahwa tingkat konsumsi oksigen bukan hanya dipengaruhi oleh salinitas namun dipengaruhi salah satunya oleh suhu. Konsumsi oksigen adalah indikator respirasi yang juga menunjukkan metabolisme energetik. Selain itu, Rusdi (2006) menambahkan bahwa adapun proses metabolisme tersebut 
akan menghasilkan energi, yang selanjutnya akan digunakan untuk mempertahankan hidup termasuk adaptasi terhadap lingkungan seperti salinitas.

Perlakuan terbaik terdapat pada perlakuan C (19 ppt) dan D (14 ppt) dengan laju konsumsi oksigen (LKO) terendah. Hal tersebut disebabkan energi yang dibutuhkan untuk menyeimbangkan tekanan osmotik antara lingkungan dengan tubuhnya tidak terlalu besar. Yurisma, et al., (2013) menyatakan bahwa apabila oksigen yang dikonsumsi tinggi maka metabolisme tinggi pula, sehingga energi yang diperoleh juga tinggi.

Pertumbuhan ikan dapat dipengaruhi oleh ukuran awal ikan pada saat penelitian. Selanjutnya kemampuan adaptasi ikan terhadap salinitas juga dipengaruhi oleh umur dan tingkat perkembangannya dimana secara umum kemampuan ikan dalam osmoregulasi berbeda ditingkat umur yang berbeda. Perlakuan salinitas yang lebih rendah, selain memberi keuntungan pada peningkatan produksi juga berpotensi dapat meningkatkan efesiensi metabolisme ikan, sehingga diduga dapat meningkatkan biomassa individu. $\mathrm{Hal}$ ini diduga karena kisaran salinitas masih dalam batas toleransi ikan, sehingga dapat digunakan untuk pertumbuhan. Pertumbuhan ditinjau salah satunya dari pertambahan biomassa individu ikan, yang merupakan salah satu komponen penting untuk mengukur keberhasilan perikanan. Untuk mempertahankan sistem osmoregulasinya, ikan membutuhkan setidaknya 25 hingga 50\% dari total energinya. Kemudian ikan akan mengkonversi pakan yang dikonsumsinya menjadi biomassa jika terdapat kelebihan nutrisi setelah digunakan untuk metabolisme dasar (seperti osmoregulasi) (Bone \& More, 2008). Selanjutnya Retnani dan Abdulgani (2013) menambahkan bahwa penurunan salinitas yang lebih rendah dari salinitas air laut akan menyebabkan penurunan kebutuhan energi kerena sel chloride insang mengalami penurunan aktivitas pada pemindahan ion $\mathrm{Na}$. Hal ini yang menyebabkan sumber energi lebih banyak digunakan ikan untuk tumbuh dari pada melakukan proses osmoregulasi pada salinitas yang lebih rendah dari pada salinitas air laut.

Affandi dan Tang (2002) menyatakan bahwa ikan mempunyai tekanan osmotik yang berbeda dengan lingkungannya, maka untuk mencegah kelebihan ataupun kekurangan air dari tubuhnya ikan melakukan osmoregulasi sehingga proses-proses fisiologi di dalam tubuhnya dapat berlangsung dengan normal. Perubahan yang terjadi pada proses osmoregulasi menyebabkan peningkatan kebutuhan energi ikan untuk beradaptasi dengan perubahan lingkungan dan mengurangi alokasi energi untuk pertumbuhan (Halver dan Hardy 2002).

Berdasarkan hasil uji statistik efisiensi pakan pada benih ikan bawal bintang dengan salinitas yang berbeda berpengaruh nyata pada setiap perlakuan dengan nilai $F_{\text {hitung }} 0,874081<F_{\text {tabel }}$ $4,07(0,05)$. Pakan terbanyak dihabiskan pada perlakuan perlakuan C (19 ppt) dengan rata-rata 8,94\%, kemudian pada perlakuan D (14 ppt) dengan nilai rata-rata $8,40 \%$. Selanjutnya pada perlakuan B (24 ppt) dengan rata-rata 7,62\%, dan pada perlakuan A (kontrol 32 ppt) 5,56\%. Adapun pakan yang dikonsumsi oleh setiap hewan uji dipergunakan untuk energi untuk hidup dan tumbuh. Ikan bawal bintang merupakan ikan pemakan segala, sehingga untuk dibudidayakan sangat mudah. Berdasarkan pernyataan di atas sehingga dapat diduga bahwa benih ikan bawal bintang menyukai lingkungan dengan salinitas rendah (payau) dan lebih menyukai habitat dan lingkungan seperti pada perlakuan C dan D (19 ppt dan 14 ppt), sehingga pakan yang diberikan dapat diserap dan dimanfaatkan untuk pertumbuhan secara maksimal.

Berdasarkan hasil penelitian yang diperoleh pada perlakuan C (19 ppt) dengan jumlah pakan paling besar dihabiskan, kemudian pakan yang di konsumsi dapat diserap oleh tubuh secara maksimal untuk pertumbuhan baik panjang maupun bobot. Sehingga bobot yang dihasilkan sebanding dengan jumlah pakan yang dihabiskan. Fungsi pakan secara umum adalah sebagai sumber energi dan materi pembangun tubuh. Kecernaan serta penyerapan pakan melalui usus akan lebih efesien apabila media eksternal sedikit hipotonik di bawah rentang isoosmotik organisme akuatik euryhaline (Nugroho, 1999).

Salinitas selain berpengaruh pada pertumbuhan dan oksigen yang dikonsumsi, juga berpengaruh terhadap kemampuan ikan tersebut untuk hidup dan dalam mentoleransi lingkungan dengan salinitas yang lebih rendah. Perlakuan kontrol (32 ppt) benih ikan bawal bintang kurang mentolerir kadar salinitas untuk hidup. Sehingga pada perlakuan dengan salinitas 32 ppt tingkat kelangsungan hidup (SR) lebih rendah, jika dibandingkan dengan tingkat kelangsungan hidup (SR) pada salinitas yang lebih rendah (payau). Secara alamiah setiap organisme mempunyai kemampuan untuk menyesuaikan diri terhadap perubahan-perubahan yang terjadi dilingkungannya dalam batas-batas tertentu atau disebut tingkat toleransi. Jika perubahan lingkungannya terjadi di luar kisaran toleransi suatu hewan, maka cepat atau lambat hewan tersebut akan mati (Hoar, 1979).

Apabila dibandingkan tingkat kelangsungan hidup pada setiap perlakuan, masing-masing benih ikan bawal bintang masih bisa mentoleransi salinitas yang ada. Hal tersebut dapat dilihat dari jumlah benih yang dipelihara dari awal penelitian hingga pada akhir pemeliharaan, dimana jumlah mortalitas yang didapat tidak rendah, dengan nilai kelangsungan hidup pada masing masing perlakuan diatas $50 \%$. Dari hasil tersebut masih dikatakan aman apabila diaplikasikan pada kegiatan budidaya, baik pada salinitas normal ataupun salinitas lebih rendah (payau). Hal tersebut sesuai dengan Retnani dan Abdulgani (2013) yang menyatakan bahwa benih ikan bawal bintang dapat hidup pada salinitas terendah sekitar 4 ppt dengan tingkat kelangsungan hidupnya $100 \%$.

Kualitas air yang diperoleh selama penelitian 28 hari masih dikatakan baik dengan nilai suhu rata-rata yang diperoleh selama penelitian berkisar antara 26,3-30,5 dan $\mathrm{pH}$ berkisar 7,89-8,27. Menurut SNI (7901. 4. 2013) kualitas air yang baik bagi benih ikan bawal bintang suhu $28-32^{\circ} \mathrm{C}$ dan $\mathrm{pH} 7,5-8,5$. Dengan demikian kisaran $\mathrm{pH}$ selama masa pemeliharaan masih termasuk dalam kisaran yang baik bagi kelangsungan hidup ikan bawal bintang. Kemudian DO yang diperoleh yaitu berkisar 5, $25-6,12$ $\mathrm{mg} / \mathrm{l}$. Hasil tersebut sesuai dengan SNI (7901. 4. 2013) yang menyatakan bahwa DO yang baik untuk pemeliharaan benih bawal bintang $>5 \mathrm{mg} / \mathrm{L}$. Hasil pengukuran DO selama masa pemeliharaan menunjukan nilai yang cukup baik untuk kehidupan bawal bintang. Kemudian setiap perlakuan memiliki tingkat salinitas yang berbeda-beda dengan salinitas kontrol 32 ppt, 24 ppt, 19 ppt dan 14 ppt. Salinitas dapat bervariasi secara luas di daerah teluk dan estuari yang dipengaruhi oleh aliran arus, aliran air tawar, dan evaporasi (Stickney, 2000). Amoniak yang diperoleh selama penelitian berkisar 0,16-0,24 ppm. Hasil tersebut masih dalam batas aman untuk pemeliharaan benih bawal bintang. Hal ini sesuai dengan SNI (7901. 4. 2013) untuk pemeliharaan benih bawal bintang, nilai amoniak maksimal 1 $\mathrm{mg} / \mathrm{L}$.

\section{Kesimpulan}

Salinitas berpengaruh Sangat Nyata terhadap Laju Konsumsi Oksigen pada benih bawal bintang (Trachinotus blochii). Perlakuan D (14 ppt) memiliki laju konsumsi oksigen tertinggi sebesar $0,47 \mathrm{mg} \mathrm{O}_{2} / \mathrm{g} / \mathrm{jam}$, pertambahan panjang 
tertinggi sebesar $1,52 \mathrm{~cm}$ dan kelangsungan hidup tertinggi sebesar $100 \%$. Perlakuan C (19 ppt) juga memiliki pertambahan bobot tertinggi sebesar 2,72 gram dan efisiensi pakan tertinggi sebesar $8,94 \%$. Ikan bawal bintang dapat hidup secara optimal pada rentang salinitas $14-19$ ppt.

\section{Bibliografi}

Affandi, R., Tang, U.M., 2002. Fisiologi Hewan Air. Pekanbaru (ID): UNRI Press.

Anggoro, S., 1992. Efek Osmotik Berbagai Tingkat Salinitas Media Terhadap Daya Tetas Telur dan Vitalitas Larva Udang Windu (Penaeus monodon) Fabricius. Institut Pertanian Bogor, Bogor.

Asnawi, Suhaimi, 1993. Pemeliharaan Ikan Dalam Keramba. PT Gramedia. Jakarta. HIm 33-44.

Effendi, 1979. Metode Biologi Perikanan. Bogor (ID): Dewi Sri Bogor. 112 hal.

Halver, J.E., Hardy, R.W., 2002. Fish Nutrition. Third Edition. Academic Press, Inc. University of Washington. Seattle. Washington.

Hartono, N., Hermawan, T., Dikrurahman, Aprianing, S., 2010. Budidaya Ikan Bawal Bintang (Trachinotus blochii). Balai Budidaya Laut Batam, Direktorat Perikanan Budidaya Departemen Kelautan dan Perikanan.

Hoar, W. S., 1979. Fish Physiology Vol. III Bioenergetics and Growth. Academic Press. New York. Hal 270-340.

Hutami, T. R., Nurlita, A., Pengaruh Salinitas Terhadap Kandungan Protein Dan Pertumbuhan Ikan Bawal Bintang (Trachinotus blochii). Jurnal Sains Dan Seni POMITS. Vol 2. No. 2. Tahun 2013.

KKP, 2012. Keputusan Menteri Kelautan dan Perikanan Republik Indonesia Nomor Kep.47/Men/2012 tentang Pelepasan Nila merah nilasa. Kementrian Kelautan dan Perikanan. Jakarta.

McMaster, M.F., Kloth, T.C., Coburn, J.F., 2005. Pampano Mericulture In Low Salinity Ponds. $2^{\text {nd }}$ Internasiaonal Sustainable Marine Fish Culture Conference and Workshop At Harbor Branch Oceanographic Institusion, Fort pierce, Florida.

Minjoyo, H., Prihaningrum, A., Istikomah, 2008. Pembesaran Bawal Bintang (Trachinotus blochii, Lacepede) Dengan Padat Tebar Berbeda di Keramba Jaring Apung. Diakses dari www.jurnal.pdii.lipi.go.id.

Nugroho, A., 1999. Pengaruh Salinitas terhadap Tingkat Kerja Osmotik, Konsumsi Pakan, Pertumbuhan dan Efisiensi Pakan Juwana Ikan Kakap Putih (Lates calcalifer) [Tesis]. Bogor (ID): Institut Pertanian Bogor.

Resley, M. J., Kenneth, A., Webb, Jr., Holt, G. J., 2006. Growth and Survival of Juvenil Cobia, Rachycentron canadum, at Different Salinities in a Recirculating Aquaculture System. Aquaculture, 253:398-407.
Retnani, T.H., Abdulgani, N., 2013. Pengaruh salinitas terhadap kandungan protein dan pertumbuhan ikan bawal bintang (Trachinotus blochii). Jurnal Sains dan Seni Pomits, 2(2):177-181.

Saanin, H., 1984. Taksonomi dan Kunci Identifikasi Ikan. Bina Cipta. Jakarta.

SNI 7901.4.2013 tentang ikan Bawal Bintang (Trachinotus blochii, lecepede) Bagian 4. Produksi Benih.

Stickney, R.R., 2000. Encyclopedia of aquaculture. A WileyInterscience Publication John Wiley \& Sons, Inc. The United States of America, 1,063 pp.

Tim Balai Budidaya Laut Batam. 1999. Pembenihan Bawal Bintang (Trachinotus blochii, lecepede). Balai Budidaya Laut Batam- Departemen Kelautan dan Perikanan Batam.

Wibowo. H., Gunarso, 1999. Pembenihan Bawal Bintang (Trachinotus blochii, lacepede). DEPTAN. Dirjen perikanan. Loka Budidaya Laut Batam. Batam.

Yurisma, E., Abdulgani., Mahasri. 2013. Pengaruh Salinitas Yang Berbeda terhadap Laju Konsumsi Oksigen Ikan Gurame (Osprhonemus gouramy). Jurnal Sains dan Seni, Vol. 1, No. 1.

Zonneveld, N., Huisman, E.A., Boon, J.H., 1991. Prinsip-prinsip Budidayalkan.PT. Gramedia Pustaka Utama. $318 \mathrm{hlm}$. 